\title{
The Aqiqah and Circumcision in the Bajo Tribe Tradition : An Overview of Cultural Acculturation
}

\author{
Ferlin Anwar' ${ }^{1}$, Mustakimah ${ }^{1}$, Roni Mohammad ${ }^{2}$, Muhammad Obie $^{3 *}$ \\ ${ }^{1}$ Department of Philosophy, State Islamic University of Sultan Amai Gorontalo, Indonesia \\ ${ }^{2}$ Department of Economics, State Islamic University of Sultan Amai Gorontalo, Indonesia \\ ${ }^{3}$ Department of Sociology, State Islamic University of Sultan Amai Gorontalo, Indonesia \\ *Corresponding Author Email: obiclimber@gmail.com
}

\begin{abstract}
This study analyzed the rituals of aqiqah and circumcision, along with the inclusion of Islam in the Bajo tribe life. The research used a qualitative approach with a case study and ethnographic methods. Informants, as primary data sources, were selected by purposive sampling and snowball techniques. The researchers collected data through observation, interviews, focused group discussions, and document reviews. The researchers then analyzed the data by grouping, making a sequence, and abbreviating the data so that it was easy to read. The results stated that long before embracing Islam, the Bajo tribe had a tradition that was upheld by the people. After adopting Islam as a new religion for them, the practice of old traditions that have been passed down since their ancestors retained it. Then there is the acculturation of Islamic values in the Bajo culture. Aqiqah and circumcision, which are Islamic orders, are accepted and practiced by the Bajo by utilizing the ritual traditions they used to do before Islam. Values of worship of the spirit along with its main ingredients such as betel leaves, turmeric, areca nut, etcetera are maintained in the practice of aqiqah and circumcision by adopting the recitation of remembrance sourced from the al Qur'an.
\end{abstract}

Keywords : Aqiqah, Circumcision, Tradition, Bajo Tribe, Cultural Acculturation

\section{INTRODUCTION}

Aqiqah and circumcision are practiced in local traditions as the community accepts Islam. Islam, in its presence on this earth, mingles with a variety of local cultures. Islam and local culture in a society cannot be separated, both of which are mutually supporting and encouraging. Islam as a religion revealed by Allah for all mankind has played its role in filling the lives of humankind on this earth. The presence of Islam in a society that already has its own culture, makes Islam with the local culture undergo acculturation, which in turn governs the implementation of Islamic orders to be diverse.
However, al-Qur'an and Hadith, as sources of Islamic law continue to spearhead the majority Muslim community, so that Islam is so synonymous with diversity (Miharja, 2014).

In general, the concept of Islam, humans have two patterns of relationships, namely vertical relationships with Allah and relationships with fellow human beings. The first relationship takes the form of a religious order (worship), while the second relationship forms social relations. Social relations forms society, which becomes a cultural container (Gazalba, 1989). Tradition is a hereditary custom that is still carried out in society, an assessment, or the 
assumption that the methods that already exist are the best and the right (Rais, 2012). Islam is an order that is related to other traditions. Sometimes these relationships give rise to new traditions, a tradition of hybridization or marriage between Islam on the one hand and local traditions on the other.

Luthfi (2016) analyzes the concept of Nusantara Islam in terms of the structure of Islamic relations theory and local culture found that Islam influenced Indonesian culture. This finding is in line with Umam (2015), who raised the topic "Acculturation of Islam and Local Culture in Agrarian Communities (Experience of Klutuk Peasants in Indramayu Regency)." The researcher explains that Islam, although many aspects are different from the traditional view held by peasants when Islam is present, it tries to fill the space that has not been obtained by the people holding the tradition. This space is the value of transcendence and the order of sharing with others that they did not find before either in the religion of the ancestors or afterward, until the arrival of Islam. Through the efforts made by its announcer, Islam has increasingly dominated the views and values prevailing in the tradition, without losing its locality and cultural context. In other words, the form is relatively fixed, but the value and meaning are different.

Widiana (2015) examines the topic "The Struggle of Islam with Local Culture. The Samin Community Case Study in the Bojonegoro Japanese Hamlet ", explains that the Samin community's understanding of Islam is related to theology, worship (ritual), and social relation, still inherited by the orders of Saminism. Islam is understood in terms of the orders of Samin, so the essence of the orders is integrated, but the practice of worship (rituals) of Islam has not been implemented. There was a syncretic practice (typical of Samin Islam) because Samin's orders accommodated Islamic orders.
In line with the above findings, Aziz (2013) in his research explained that the entry of Islam into Java, in the context of culture had an impact on the acculturation of Islam and Javanese culture, namely cultures that had lived and developed during the heyday of the Javanese Hindu kingdoms. Acculturation of Islam and Javanese culture can be seen in tombstones, architecture, literary arts, carving, and various traditions celebrating Islamic holidays. Islamic acculturation and Javanese culture can be seen in every era of the empire (Islamic kingdom) in Java, both the Demak era, the Pajang era, and the Islamic Mataram era. In the era of Demak, acculturation between Islam and Javanese culture occurred in many ways, such as architecture, carving, puppet art, funeral patterns, and literary arts (such as chronicle, saga, and others).

Aghsari and Wekke (2015) analyze the research topic "Sasi Laut Ritual: Acculturation of Religion and Culture in the Ritual Practices of the Missol Raja Ampat Community." The researchers explaine that the sasi laut before the arrival of Islam was carried out in order to respect the leaders. After the Islamic religion reached Papua around the 15th century, the sasi laut then changed in its "designation" and "process." Islam comes and instills Islamic values, such as salawat to the Prophet Muhammad, prayer facilitates fortune, and prayer of salvation. Changes that occur in the sasi laut ritual is acculturation between the Missol community culture with Islam. The religion of Islam changes the mindset of the people, eliminating things that can cause shirk, but does not eliminate the characteristics and the main parts of the sasi laut ritual.

In line with the explanation above, this study analyzes the inclusion of Islam, as well as the aqiqah and circumcision traditions in the Bajo Tribe culture in Tomini Bay. Although the Bajo have accepted Islam, in practice it is still influenced by their original 
beliefs. The circumcision ritual is an Islamic suggestion that practice in the Bajo community is juxtaposed with ancestral traditions. Likewise, the hairdressing scissors ceremony or aqiqah is an Islamic order which implementation in the Bajo community is also juxtaposed with ancestral traditions.

\section{LITERATURE REVIEW}

Culture is a complex whole of knowledge, beliefs, arts, morals, laws, customs, and other abilities and habits acquired by humans as members of society (Tylor, in Tilaar, 2004). Williams (1990) states that culture includes the organization of production, the structure of the family, the structure of institutions that express or regulate social relations, a form of communication that is unique in community members. Levi-Strauss (2005) explains that culture must be seen in the context of communication theory, namely as a whole system of symbols (language, kinship, economics, myths, art) which at various levels enable and regulate communication.

Koentjaraningrat (2000) defines culture in the narrow and broad sense. In a narrow sense, culture is art, while in a broad sense, culture is the whole idea and works of humans, which must be familiarized with learning, along with the whole of the results of his mind and work. Varner and Beamer (2011) state that culture is a coherent view of something that is learned, shared, or exchanged by a group of people. Meanwhile, Samovar et al. (2010) provides the view that culture can mean accumulative reserves of knowledge, experience, beliefs, values, attitudes, meanings, hierarchy, religion, choice of time, roles, relations of space, broad concepts and material objects or ownership owned and maintained by a group person or a generation.

Cultural elements, according to Koentjaraningrat (2000), consist of 1) religious systems and religious ceremonies; 2) community systems and organizations; 3) knowledge systems; 4) language; 5) artistry; 6) livelihood systems; and 7) systems of technology and equipment. The form of culture, according to Koentjaraningrat (2000) consists of 1) an idiotic form that is abstract, cannot be touched. It is located in the mind of the community members where the culture concerned lives, which appears in compositions, songs. Its functions are regulators, organizers, controllers, and givers in the direction of human behavior in society. Custom consists of several layers, namely the cultural value system (the most abstract and broad), the system of norms (more concrete), and special rules regarding various daily activities (rules of courtesy) that are the most concrete and limited in scope. 2) The second form is a social system regarding the patterned behavior of humans themselves. This social system consists of interacting with human activities that always follow specific patterns. It is concrete and observable. 3) The third form is the most concrete physical culture and objects that can be touched and seen.

Swansea (in Mariane, 2014) states that local wisdom and local excellence are social policies that rely on traditionally institutionalized values, methods, and behavior. Local wisdom is a value that is considered good and right, so that it can last for a long time, even institutionalized. Chambers (1983) asserts that every society has traditional knowledge and technology called "rural folk knowledge." Traditional knowledge and technology, if passed down from generation to generation into the tradition (Giddens, 2003). A tradition is extensive in scope, one of which is the traditional wisdom. Keraf (2002) argues that traditional wisdom not only concerns knowledge, understanding, and customs about humans, nature and how good relations are among people but also concerns knowledge, understanding, and customs about humans, nature, and how relations between all inhabitants of the ecological community. 
Keraf (2010) further explains local wisdom as follows: 1) Traditional wisdom belongs to the community. Also known as knowledge about humans, nature, and relationships in nature also belongs to the community. There is no traditional knowledge or wisdom that is individualized; 2) Traditional wisdom is a holistic property because it involves knowledge and understanding of all life with all its relations in the universe. Nature is a broader network of life than just the sum of all the parts separated from one another. Nature is a series of relationships that are related to one another, so understanding and knowledge of nature must constitute a comprehensive knowledge; and 3) Unlike western science, which claims to be universal, traditional wisdom is local because it is related to a particular and concrete place. Traditional wisdom and knowledge always concern the particular human person (the indigenous community itself) and its relationship to nature. However, because humans and nature are universal, traditional wisdom and knowledge are not even engineered to be universal in themselves.

Although it does not have a universal formula as it is known in modern science, traditional wisdom is found in all indigenous peoples or tribes around the world, with the same substance, both in the technical and moral dimensions. Meanwhile, in its interaction with other cultures, a culture allows acculturation. Poerwanto (2000) states that acculturation is a cultural contact that has two ways process, mutually influencing between two groups that have a relationship to designate a reciprocal relationship between aspects of culture. Redfield et al. (1936) state that acculturation includes phenomena that have been produced since two groups with different cultures began to make direct contact, followed by the original cultural patterns of one or both groups. Haviland (1985) states that acculturation is significant changes in culture that occur as a result of prolonged contact between cultures.

Koentjaraningrat (1993) states that acculturation is a form of social process that arises when a group of people with a particular culture is confronted with elements of foreign culture (cultural contact occurs), in which foreign cultural elements are gradually accepted and processed into their own culture without eliminating the elements of the culture's personality. Furthermore, Koentjaraningrat (1993) stated several things in the acculturation process: (1) The state of the recipient community, before the acculturation process began; (2) Individuals who carry elements of foreign culture; (3) Channels used by elements of foreign culture to enter the foreign culture; and (4) Reactions from individuals affected by foreign cultures.

Linton (1940) provides a concept of cultural elements that are distinguished between elements of culture that are easily changed and those that are difficult to change. Furthermore, Linton explained that the core parts of culture as elements of culture that are difficult to change are: cultural value systems; religious beliefs that are considered sacred; some customs that have been learned very early in the process of socializing individual community members; and some customs that have an extensive net function in the community. In contrast, the part of the culture as an element of culture that is easily changed is physical culture such as tools and useful objects, science, patterns of lifestyle or recreation, and recreation.

Foster (1962) explains that: 1) The acculturation process can begin in the upper classes living in cities, then spread to lower classes in rural areas. This kind of process usually starts from socioeconomic changes; 2) Changes in the economic sector can cause essential changes in the principles of family life; 3) Planting 
crops for export (trade commodities) and the development of a money economy undermine traditional patterns of cooperation, due to the development of a new labor deployment system; 4) The development of the economic system of money also causes changes in eating habits that result in aspects of economic and socio-cultural nutrition; 5) The process of acculturation that is developing rapidly causes a variety of social shifts that are not uniform in all elements and sectors of society. So that there are community gaps that have the potential for social conflict in the community.

\section{METHODS AND MATERIAL}

This research was conducted in the Bajo tribe community of Tomini bay - Indonesia using a qualitative approach, case study methods, and ethnography. The case study method was intended so that the cases studied to become more focused (Surakhmad, 1982). The case of this study was aqiqah and circumcision rituals along with the inclusion of Islam in the Bajo tribe community. Meanwhile, ethnographic methods were used to understand the Bajo views in the practice of aqiqah and circumcision rituals (Spradley, 2007).

Informants, as primary data sources, were selected by purposive sampling and snowball techniques. The technique of determining informants purposively means that the selection of informants was based on the rational considerations of researchers who were considered to have the competence to provide information or data expected by the researchers. Herdiansyah (2011) states that purposive sampling is used to select research subjects and research locations to study and understand the problems and research objectives.

Data collection was done through several techniques, namely passive participation observation, in-depth interviews, Focused Group Discussion (FGD), and document review. Observation of passive participation, namely observing the subjects of the study openly, but not involved in these activities (Stainback \& Stainback, 1988). Meanwhile, in-depth interviews are conversations with a specific purpose (Moleong, 2007). According to Banister et al. (1994), interviews are conversations and questions and answers directed to achieve specific goals. Interviewing in a qualitative approach is to gain knowledge about the subjective meanings understood by the individual regarding the topic under study, and the purpose is to explore the issue, something that cannot be done through other approaches. Nazir (2003) defines interviewing as the process of obtaining information for research purposes through question and answer while meeting face to face using a tool called an interview guide.

The purpose of conducting an interview is to construct people, events, organizations, feelings, motivations, demands, concerns, and others (Lincoln \& Guba, 1985). As for in-depth interviews in this study, researchers applied a semi-structured interview. Meanwhile, the method of reviewing documents is to study the data obtained from existing documents. After that, data collection is also carried out through FGD activities, which are to explore deeper issues and to obtain more precise information because it allows FGD participants to check the information conveyed to each other. According to Kriyantono (2006), the FGD method is a data collection technique to understand the attitudes and behavior of the audience and unstructured discussion with the topic prepared. As for things to consider in the FGD, namely: (1) There are no right or wrong answers every FGD participant must feel free to answer according to the problem of the discussion; (2) all interactions and conversations must be appropriately recorded; (3) the discussion must take place in an informal atmosphere so that participants can provide comments even if 
they are not asked directly so that a dynamic exchange of opinions occurs.

After the data collected, the researchers then conducted the data analysis. Nasir (2003) revealed that data analysis is grouping, making a sequence, manipulating, and abbreviating data so that it is easy to read. Poerwandari (2007) states that data processing and analysis actually starts with organizing data. Many and varied qualitative data are the obligation of researchers to organize the data neatly, systematically, and as completely as possible. Highlen and Finley (1996) state that data organization allows researchers to 1) obtain useful quality data; 2) document the analysis carried out; 3) save data and analysis related to the completion of the research.

\section{RESULTS AND DISCUSSION}

When Islam came in the early thirteenth century to the archipelago, the preachers taught Islam that was able to be well received by the community. The role of Islamic broadcasters in instilling new values in this entrenched tradition creates a new color in the culture of society. The process begins with carrying out social activities in society, conducting kinship relationships with the marriage path, also instilling Islamic knowledge in the community. From this compelling way, Islam is gradually accepted and known as a religion that carries new values and orders that can complement the shortcomings of the old religion they profess. Even so, many traditions that have been firmly rooted in the community are still maintained by them, but with different values and meanings (Umam, 2015).

Islam is a religion that has universal characteristics, with a view of life about equality, justice, freedom, and honor and has the concept of humanistic theism as a core value of all Islamic orders, and therefore a theme of Islamic civilization (Kuntowijaya, 1991). At the same time, in translating the concepts of heaven to earth, Islam has a dynamic, elastic and accommodating character to the local culture, as long as it does not conflict with Islamic principles themselves. It is also noteworthy that popular culture in Indonesia absorbs a lot of Islamic concepts and symbols, so it often seems that Islam emerges as an essential cultural source in popular culture in Indonesia (Asnawan, 2011).

The archipelago before the arrival of Islam had established kingdoms that were characterized by Hinduism and Buddhism, such as the kingdoms of Srivijaya and Majapahit. After the process of Islamization, which began in the 13th century, elements of the Islamic religion played an essential role in establishing a communication network between the coastal kingdoms and the inland kingdoms that were still Hindu-Buddhist in style (Hamka, 1981).

The process of acculturation of Islam and culture is known as the Islamization of culture approach. Through this approach, the local culture is directed so that it appears to be patterned in Islam both formally and substantially characterized by the use of Islamic terms, Islamic names, the taking of the role of Islamic figures in various old stories, to the application of Islamic laws, and norms in various aspects of life (Nuryah, 2016).

When Islam spread throughout the archipelago, Islam could not be separated from the local culture that already existed in society. Between the two requires a creative and dynamic dialogue, until finally, Islam can be accepted as a new religion without having to displace the existing local culture. In this case, local culture that is tangible in the traditions and customs of the local community can still be done without hurting Islamic orders; otherwise, Islam can still be 
taught without disturbing the harmony of community traditions (Widiana, 2015).

Since the beginning of its development, Islam in the archipelago is a native Islam spread by Walisongo and their followers by carrying out cultural transformation in society. Islam and tradition are not placed in a face-to-face position but are seated within a framework of creative dialogue, where transformation is expected to occur. The process of cultural transformation, in turn, produces a combination of two entities, namely Islam and local culture. This combination fosters Islamic traditions, which are still practiced in various cultural Islamic communities in Indonesia (Widiana, 2015).

The Bajo people like local tribes in the archipelago have traditions, customs, and other cultures that were practiced in their communities long before the entry of Islam. The Bajo people know Islam from Malikkussaleh (Sultan of Aceh) in the thirteenth century. Their meeting with the Sultan of Aceh led the Bajo to embrace Islam (Baskara, 2016). When the Bajo tribe embraced Islam, the culture that had taken root in daily life was acculturated with Islamic values. Bajo tribes still maintain their culture, but on the other hand, they also accept Islamic sharia (Lahaji \& Obie, 2020). Aqiqah and circumcision in its implementation require the baby's parents to prepare unique materials which, of course, have specific values for the community. The aqiqah preparation materials in the Bajo tribe consist of goats, mirrors, combs, powder, combs, pandan leaves, white cloth, coconut oil, betel leaves, turmeric, and betel nuts. After the ingredients are prepared, the process of cutting goats is done by first bathing it. After bathing, goat hairs are combed and powdered. The goat is then slammed on a white cloth base, with thread attached to its mouth. In slaughtering, the goat is slaughtered and the baby's parents are shown a mirror so that their reflection is seen in the mirror.
The process of cooking aqiqah mutton meat also has its own provisions. The head of a goat may not be put together with meat and other body parts. The chest is roasted, and the ribs must not be crushed. The head of the ripe goat is served before the priest. The remnants of the slaughter must not be discarded and must be tidied up until the aqiqah prayer is over. In the Bajo tribal community, aqiqah prayer is led by a village priest.

The implementation of qiqah in the Bajo tribe community, before slaughtering the aqiqah goat, in the evening there is a certain ritual, which is to read the al Qur'an, the letter of Ikhlas and prayer beads 3,333 times. That number is calculated using stones. The number of people who read the al Qur'an and prayer beads is five people or less depending on the number of people attending the ritual. In the morning, the aqiqah begins with the reading of the barsanji and is followed by cutting the baby's hair, which is accompanied by the salawat chanting. The ingredients that must be prepared when the hair clippers consist of young coconuts that have been perforated by the head, scissors, and wax. The cut hair is stored in a young coconut, then hung next to the house. Aqiqah in the Bajo tribe community is carried out at the earliest a week after the birth of a baby and so depends on the ability of the baby's parents.

Meanwhile, circumcision in the Bajo tribe community is carried out by first preparing materials such as chickens that have crested, chicken eggs, turmeric, rice, wax, lime, betel leaves, and betel nuts. The process of implementation is after being slaughtered, the chicken is crested, and the blood is drawn. Chicken blood was rubbed on certain parts of the circumcised child, namely the forehead and temples left and right. Circumcised children wear black skulls and sarongs. In the process, white rice and yellow rice were served. White rice is placed facing the land, while yellow rice is facing the sea. 
After the child is circumcised, the mother accompanies him on the left or right. The child's mother will wet the side of her child's hair and rub it. This is done to strengthen the hearts of children who have been circumcised. Circumcised children are then given sago porridge.

The Bajo tribe believes certain restrictions that should not be violated by a child who has just finished circumcision. Abstinence, among others, may not step over chicken and not eat baronang fishes. If this abstinence is violated, the circumcision will swell. In line with this finding, various taboos in the Bajo tribe community relate to belief in spirits, which has an applicative effect on environmental preservation (Obie, 2016; Obie, 2018; Obie et al., 2020). Bajo people are prohibited from violating the existing restrictions because it can cause disaster for the perpetrators. Their beliefs influence these taboos in the Bajo before Islam. Obie et al. (2016) state that Bajo people view Coastal and marine resources as part of their lives, so they treat these resources wisely.

The practice of aqiqah and circumcision in the Bajo tribe community, as described above, seems to have occurred the acculturation of the Bajo culture, which was handed down traditionally from their ancestors, with Islamic orders that came later. The Bajo, who initially embraced animism, accepted the Islamic orders that did not wholly abandon their traditions at sea. Worship to the sea authorities, which they applied by performing certain rituals when they wanted to go to sea to some issues, was also juxtaposed with the orders of Islam in carrying out the practice of aqiqah and circumcision. Ritual materials commonly used when they want to do activities at sea are also used in aqiqah and circumcision rituals. Ingredients such as lime, betel leaves, and betel nuts are essential ingredients commonly used in sea rituals, also used in the implementation of aqiqah and circumcision.
According to the Bajo people, these materials are favored by the spirits of the sea authorities, so they must be held in the ritual. Likewise, the determination of the location of ritual materials also has its value for Bajo people. White rice in the implementation of circumcision must face the land, while yellow rice faces the sea, for example, has the value of respect for the spirits on land and the spirit of the sea lord. This is done because Bajo people believe that every substance in the world (macro cosmos) has a guard that requires Bajo people not to speak and act carelessly. This finding is in line with Obie (2015) that the Bajo people see that all the resources around their residence at sea have guardians by the spirits. Mangrove trees are guarded by spirits that inhabit mangroves, coral reefs are guarded by spirits inhabiting coral reefs, and spirits of sea dwellers guard the sea.

\section{CONCLUSION}

Long before embracing Islam, the Bajo tribe had a tradition that was upheld by the people. The Bajo culture at that time was attached to the natural environment, in which the Bajo people conceptualized themselves as part of it. After interacting with Islam and embracing it as a new religion for them, the old culture that has been passed down since their ancestors were acculturated with Islam. The practice of Bajo tribal traditions accept Islamic values where the Islamic orders are combined with the practice of the Bajo tribe tradition. Aqiqah and circumcision, which are the orders of Islam, are accepted and practiced by the Bajo Tribe by utilizing the ritual traditions that are commonly practiced in the Bajo Tribe community itself. So then, the rituals of aqiqah and circumcision, which are the Islam orders in its implementation, acculturate with the Bajo tribal traditions. The values of worship of the spirit along with its main ingredients such as betel leaf, turmeric, areca nut, etc. are maintained in the 
practice of aqiqah and circumcision by adopting the recitation of remembrance sourced from $\mathrm{Al}$ Quran.

\section{REFERENCES}

[1]. Aghsari, D., \& Wekke, I. S. (2015). Ritual Sasi Laut: Aluturasi Agama dan Budaya dalam Praktik Ritual Kebaharian Masyarakat Missol Raja Ampat. Jurnal Airaha, 4(1), 11-17.

[2]. Asnawan. (2011). Islam dan Akulturasi Budaya Lokal di Indonesia. Jurnal Falasifa, 2(2), 85-96.

[3]. Aziz, D. K. (2013). Akulturasi Islam dan Budaya Jawa. Fikrah, I(2), 253-286. http://dx.doi.org/10.21043/fikrah.v1i2.543.

[4]. Banister, P., Buman, E., Parker, I., Taylor, M., \& Tindall, C. (1994). Qualitative Methods in Psychology: A Research Guide. Buckingham: Open University Press

[5]. Baskara, B. (2016). Islam Bajo: Agama Orang Bajo. Tangeran Selatan, Banten: PT. Kaurama Buana Antara

[6]. Chambers, R. (1983). Pembangunan Desa Mulai dari Belakang. Jakarta: LP3ES.

[7]. Foster, G. M. (1962). Traditional Cultures and the Impact of Technological Change. New York: Harper \& Bros.

[8]. Gazalba, S. (1989). Masyarakat Islam: Pengantar Sosiologi dan Sosiografi, Cetatakan II. Jakarta: Bulan Bintang.

[9]. Giddens, A. (2003). The Constitution of Society Teori Strukturasi untuk Analisis Sosial. Pasuruan: Pedaty.

[10]. Hamka. (1981). Sejarah Umat Islam IV (Cet. III). Jakarta: Bulan Bintang.

[11]. Highlen, P. S., \& Finley, H. C. (1996). Doing Qualitative Analysis in F. T. Leong \& J. T. Austin (Eds). The Psychology Research Handbook: A guide for graduate students and research assistants. Thousand Oaks, CA: Sage.

[12]. Haviland, W. A. (1985). Antropologi, Jilid 2. Jakarta: Erlangga
[13]. Herdiansyah, H. (2011). Metodologi Penelitian Kualitatif untuk Ilmu-Ilmu Sosial. Jakarta: Salemba Humanika

[14]. Keraf, S. (2010). Etika Lingkungan Hidup. Jakarta: PT. Kompas Media Nusantara.

[15]. Koentjaraningrat. (1993). Masalah Kebudayaan dan Integrasi Nasional. Jakarta: UI Press.

[16]. Koentaraningrat. (2000). Kebudayaan, Mentalitas dan Pembangunan. Jakarta: PT. Gramedia Pustaka Utama.

[17]. Kuntowijoyo. (1991). Paradigma Islam: Interpretasi untuk Aksi. Bandung: Mizan.

[18]. Kriyantono, R. (2006). Teknik Praktis Riset Komunikasi. Jakarta: Kencana.

[19]. Lahaji, \& Obie, M. (2020). Local Wisdom of the Bajo Tribe and Its Acculturation on Islamic Sharia: A Case in Tomini Bay - Indonesia. Humanities \& Social Sciences Reviews, 8(1), 814820. https://doi.org/10.18510/hssr.2020.8197.

[20]. Levi-Strauss, C. (2005). Mitos dan Makna: Membongkar Kode-Kode Budaya. Tangerang: Marjin Kiri.

[21]. Lincoln, Y. S. \& Guba, E. G. (1985). Naturalistic Inquiry. California: Sage.

[22]. Linton, R. (1940). Acculturation in Ralph Linton (Ed). Acculturation in Seven American Indian Tribes. Gloucester: Peter Smith.

[23]. Luthfi, K. M. (2016). Islam Nusantara: Relasi Islam dan Budaya Lokal. Shahih, 1(1), 1-12. https://dx.doi.org/10.22515/shahih.v1i1.53.

[24]. Mariane, I. (2014). Kearifan Lokal Pengelolaan Hutan Adat. Jakarta: Rajawali Pers.

[25]. Miharja, D. (2014). Persentuhan Agama Islam dengan Kebudayaan Asli Indonesia. Miqot, XXXVIII(1), 189-214. http://dx.doi.org/10.30821/miqot.v38i1.97.

[26]. Moleong, L. J. (2007). Metodologi Penelitian Kualitatif (Edisi Revisi). Bandung: PT. Remaja Rosda Karya.

[27]. Nazir, M. (2003). Metode Penelitian. Jakarta: Ghalia Indonesia. 
[28]. Nuryah. (2016). Tedhak Siten: Akulturasi Budaya Islam-Jawa (Studi Kasus di Desa Kedawung, Kecamatan Pejagoan, Kabupaten Kebumen. Fikri, Vol. 1 (2), 315 - 334.

[29]. Obie, M. Soetarto, E., Sumarti, T., \& Saharuddin. (2014). Konflik Etnis di Pesisir Teluk Tomini: Tinjauan Sosio-Ekologi Politik. Al-Tahrir, 14(2), 321-342. https://doi.org/10.21154/altahrir.v14i2.75

[30]. Obie, M. (2015). Perampasan Hak Ulayat Pesisir Dan Laut Komunitas Suku Bajo (Kasus Pengelolaan Sumber Daya Pesisir Dan Laut Di Teluk Tomini). Bogor: Disertasi Sekolah Pascasarjana IPB.

[31]. Obie, M. (2016). Perubahan Sosial Pada Komunitas Suku Bajo Di Pesisir Teluk Tomini. Al-Tahrir: Jurnal Pemikiran Islam, 16(1), 153-74. https://doi.org/10.21154/al-tahrir.v16i1.377

[32]. Obie, M. (2018). Exploitation of Coastal and Marine Resources along Tomini Bay: Livelihood Base versus concession rights. Masyarakat, Kebudayaan dan Politik, 31(1), 36-45. http://dx.doi.org/10.20473/mkp.V31I12018.36-

45.

[33]. Obie, M., Pakaya, M., Mustakimah, \& Syilfi. (2020). Oil Palm Expansion and Livelihood Vulnerability on Rural Communities (A Case in Pohuwato Regency - Indonesia). Humanities \& Social Sciences Reviews, 8(1), 01-12. https://doi.org/10.18510/hssr.2020.811

[34]. Poerwandari, E. K. (2007). Pendekatatan Kualitatif untuk Penelitian Perilaku Manusia. Jakarta: LPSP3 UI.

[35]. Poerwanto, H. (2000). Kebudayaan dan Lingkungan dalam Perspektif Antropologi. Yogyakarta: Pustaka Pelajar.

[36]. Rais, H. E. (2012). Kamus Ilmiah Populer. Yogyakarta: Pusat Belajar.

[37]. Redfield, R., Linton, R., \& Herkovits, M. J. (1936). Memorandum for the Study of Acculturation. American Antropologist, New
Series,

(38(1),

149-152.

https://doi.org/10.1525/aa.1936.38.1.02a00330.

[38]. Samovar, L., Porter, R., \& McDaniel, E. R. (2010). Komunikasi Lintas Budaya. Jakarta: Salemba Humanika

[39]. Spradley, J. P. (2007). Metode Etnografi, Edisi II. Yogyakarta: Tiara Wacana.

[40]. Stainback, S., \& Stainback, W. (1988). Understanding and Conducting Qualitative Research. Reston, VA: Council for Exceptional Children

[41]. Surakhmad, W. (1982). Pengantar Penelitian Ilmiah: Dasar, Metode, Teknik. Bandung: Transito.

[42]. Tilaar, H. A. R. (2004). Multikulturalisme: Tantangan-Tantangan Global Masa Depan dalam Transformasi Pendidikan Nasional. Jakarta: Grasindo.

[43]. Umam, K. (2015). Akulturasi Islam dan Budaya Lokal pada Masyarakat Agraris (Pengalaman Petani Klutuk di Kabupaten Indramayu). Universum, 9(2), 213-223. https://doi.org/10.30762/universum.v9i2.87.

[44].Varner, I., \& Beamer, L. (2011). Intercultural Communication in the Global Workplace. New York: Mc Graw Hill.

[45]. Widiana, N. (2015). Pergumulan Islam dengan Budaya Lokal. Studi Kasus Masyarakat Samin di Dusun Jepang Bojonegoro. Teologia, 26(2), 198215.

http://dx.doi.org/10.21580/teo.2015.26.2.428.

[46]. Williams, R. (1990). Television: Technology and Cultural Form. London: Shocken Books.

\section{Cite this article as :}

Ferlin Anwar, Mustakimah, Roni Mohammad, Muhammad Obie, "The Aqiqah and Circumcision in the Bajo Tribe Tradition : An Overview of Cultural Acculturation", International Journal of Scientific Research in Science and Technology (IJSRST), Online ISSN : 2395-602X, Print ISSN : 2395-6011, Volume 7 Issue 2, pp. 18-27, March-April 2020. Available at doi :

https://doi.org/10.32628/IJSRST20722

Journal URL : http://ijsrst.com/IJSRST20722 